\title{
Size structural change in lightly exploited coral reef fish communities: evidence for weak indirect effects
}

\author{
N.K. Dulvy, N.V.C. Polunin, A.C. Mill, and N.A.J. Graham
}

\begin{abstract}
Exploitation influences community structure directly through preferential removal of larger-bodied fishes and indirectly because larger-bodied fishes may exert top-down control upon other community members. We consider the direct and indirect effects of subsistence exploitation upon the size structure of coral reef fish communities along an island-scale spatial gradient of fishing intensity. We explored the effect of fishing intensity and sample date (three dates over a year) at six islands and the overall effect of fishing intensity averaged over sample dates at 13 islands. Fishing intensity consistently explained more of the variation in the size metrics than sample date. In response to exploitation, the mean weight of individuals declined by $52 \%$, the weighted average maximum size $\left(L_{\max }\right)$ declined by $25 \%$, and slopes of community size spectra steepened. The larger size classes $(>26 \mathrm{~cm})$ declined in relative numbers by $63 \%$ and relative biomass by $61 \%$ in response to exploitation. However, the numbers and biomass of the three smallest size classes $(<25 \mathrm{~cm})$ increased by $31 \%$ and $9 \%$, respectively, in response to exploitation. This increased abundance is consistent with a weak compensatory response presumably from a reduction in predation upon smaller size classes as an indirect effect of exploiting larger size classes.
\end{abstract}

\begin{abstract}
Résumé : L'exploitation affecte la structure de la communauté directement par le retrait préférentiel des poissons de grande taille et indirectement parce que les poissons de grande taille peuvent exercer un contrôle descendant sur les autres membres de la communauté. Nous avons examiné les effets directs et indirects de l'exploitation de subsistance sur la structure en taille de communautés de poissons de récifs coralliens le long d'un gradient d'intensité de pêche à l'échelle spatiale des îles. Nous avons étudié les effets de l'intensité de la pêche et de la date d'échantillonnage (trois dates au cours d'une année) à six îles, ainsi que l'effet général de l'intensité moyenne (toutes dates confondues) de la pêche à 13 îles. Dans tous les cas, l'intensité de la pêche explique une plus grande proportion de la variation des métriques reliées à la taille que la date d'échantillonnage. En réaction à l'exploitation, la masse moyenne individuelle diminue de $52 \%$, la taille maximale moyenne pondérée $\left(L_{\max }\right)$ baisse de $25 \%$ et la pente des spectres de taille de la communauté augmente. En réaction à l'exploitation, les densités relatives des classes de grande taille $(>26 \mathrm{~cm})$ diminuent de $63 \%$ et leur biomasse de $61 \%$. Cependant, les densités et les biomasses des trois classes les plus petites $(<25 \mathrm{~cm})$ augmentent respectivement de $31 \%$ et de $9 \%$. Cette densité accrue s'accorde bien avec l'existence d'une faible réaction compensatoire probablement causée par une réduction de la prédation chez les classes de plus petite taille comme effet indirect de l'exploitation des classes de plus grande taille.
\end{abstract}

[Traduit par la Rédaction]

\section{Introduction}

The body size of a species determines much of its ecology, life history, population dynamics, and vulnerability to exploitation, particularly in the sea (Charnov 1993; Pope et al. 1994; Kerr and Dickie 2001). Body size is related to life history traits such as fecundity, somatic growth rate, age at maturity, and maximum age, such that larger-bodied fishes tend to be more fecund, slower growing, and mature later in life to greater maximum ages than smaller-bodied species (Reynolds et al. 2001; Hutchings 2002). Large-bodied spe- cies exhibit relatively lower maximum rates of population increase at small population sizes than their smaller-bodied relatives, despite their higher fecundity (Myers et al. 1999; Denney et al. 2002). Consequently, larger-bodied species would be expected to be more vulnerable to a given level of exploitation than closely related smaller-bodied species, as they have a lower capacity to replace the numbers removed by exploitation (Reynolds et al. 2001). Where differences in fishing mortality can be controlled for, larger-bodied species have been found to decline at faster rates than their smallerbodied relatives (Jennings et al. 1998). This pattern appears

Received 23 May 2003. Accepted 15 December 2003. Published on the NRC Research Press Web site at http://cjfas.nrc.ca on 22 April 2004.

$\mathrm{J} 17546$

N.K. Dulvy, ${ }^{1,2}$ N.V.C. Polunin, A.C. Mill, and N.A.J. Graham. School of Marine Science and Technology, Ridley Building, University of Newcastle, Newcastle-upon-Tyne, NE1 7RU, U.K.

${ }^{1}$ Corresponding author (e-mail: n.k.dulvy@cefas.co.uk).

${ }^{2}$ Present address: Centre for Environment, Fisheries and Aquaculture Science, Pakefield Road, Lowestoft, Suffolk, NR33 OHT, U.K. 
to be robust and is detectable even in situations where fishing effort is unknown and has been described for temperate and coral reef teleosts and some elasmobranchs (Ault et al. 1998; Jennings et al. 1999b; Dulvy et al. 2000).

Not only are larger species intrinsically more vulnerable to exploitation, they tend to be more heavily targeted. Fisheries exploitation can be highly size selective: larger-bodied individuals are preferred and the rate of removal of individuals may be greater from species that attain large body sizes (Pauly et al. 1998; Jennings et al. 1999a; Pinnegar et al. 2002).

Fish communities appear to change in a consistent sizespecific manner under exploitation as a consequence of the higher vulnerability and desirability of large-bodied individuals and species (Jennings et al. 1999a, 2002). The North Sea fish community changed from 1925 to 1996 from that dominated by large-bodied, slow ground, late-maturing species to one dominated by smaller-bodied, faster growing, earlier-maturing species (Jennings et al. 1999a). The removal of larger individuals may also have indirect ecological consequences for community structure and function (Pinnegar et al. 2000; Kaiser and Jennings 2001). For example, largerbodied predators tend to feed on smaller-bodied prey, and larger competitors may restrict territory size or occupation by smaller, competitively inferior species (Pope et al. 1994; Robertson 1998). Consequently, fishing down the size spectrum might also be expected to lead to increases in the abundance of smaller size classes through reduced predation or competition.

Indirect ecological effects have been particularly apparent in fish-invertebrate interactions where the removal of fish predators has been associated with an elevated abundance of large and small prey invertebrates such as crustaceans and echinoderms in both hard and soft sediment systems (Pinnegar et al. 2000). In temperate, soft bottom systems, the repeated depletion of the Atlantic cod (Gadus morhua) has been associated with increased abundance of crustaceans, particularly the Northern shrimp (Pandalus borealis) (Worm and Myers 2003). On coral reefs, the removal of herbivorous fishes by exploitation was thought to be a factor contributing to high densities of a competitively subordinate urchin (Diadema antillarum) in Jamaica (Pennings 1996). However, there is less evidence for increased abundance of smaller fishes as a result of reduced predation or competition due to the removal of larger-bodied fishes at large spatial scales. Declines in Atlantic cod appear to have resulted in increases in a prey fish, capelin (Mallotus villosus) in the North West Atlantic shelf (Carscadden et al. 2001). Low densities of a piscivorous grouper (Plectropomus leopardus) were associated with higher densities of their prey fishes on the Great Barrier Reef, Australia (Graham et al. 2003).

Here we explore the direct and indirect effects of exploitation on the size structure of coral reef fish communities along a spatial gradient of subsistence fishing intensity across a series of 13 isolated Fijian islands. We describe the communities using three size metrics: average size of individuals, weighted average maximum size $\left(L_{\max }\right)$ of the community, and the slope of size spectra (Rice and Gislason 1996; Jennings et al. 1999a). Specifically we test whether average size of individuals, $L_{\max }$, and size spectra of fish communities change along the gradient of fishing intensity.
However, change in these metrics alone may not distinguish between the direct effects of exploitation (the removal of larger individuals) and indirect ecological effects of exploitation (increased abundance in the smallest size classes) (Gislason and Rice 1998). To distinguish between these possibilities, we examine the response of each $5-\mathrm{cm}$ size class to exploitation. We hypothesize that direct effects will be manifest as declines in the abundance of the larger size classes along the fishing intensity gradient, and indirect effects will be manifest as increases in the abundance of smallest size classes along the fishing intensity gradient. We present two comparisons: the effect of fishing and sample date (six islands, three dates) and the overall effect of fishing averaged over sample dates (13 islands) upon size metrics.

\section{Materials and methods}

The Lau Island group in the eastern division of Fiji is relatively isolated and subject only to subsistence fisheries (Dulvy et al. 2002). Fishers used non-habitat destructive gears; these included hand spears, spear guns, and hook and hand line methods. Fishers' time was evenly divided between lagoon and fringing reef coral habitats. Fish were the predominant source of dietary protein for the islands' inhabitants, and fish were captured almost exclusively for consumption by individuals and families within individual islands (Jennings and Polunin 1995c). The only other sources of dietary protein were pigs, which were consumed only on ceremonial occasions once or twice a year, and tinned tuna and meat, which was relatively expensive and consumed infrequently. There were few opportunities for intra- and inter-island trade in fish or storage of fish, as refrigeration facilities were nonexistent on the study islands apart from the largest island, Lakeba.

Each island constituted a single discrete fishing ground (qoliqoli), where the exclusive fishing rights of each island's inhabitants extend from the shoreline to approximately $200 \mathrm{~m}$ beyond the outer reef. The islands were separated by open ocean and depths of $>1000 \mathrm{~m}$; the inter-island distances ranged from 4 to $180 \mathrm{~km}$. Both poaching by fishers and movement of adult reef fishes between islands is unlikely. A fishing intensity index for each fishing ground was obtained by dividing the human population size by the length of barrier reef front measured from aerial photographs (Jennings and Polunin 1996; Dulvy et al. 2002).

Fish were censused on shallow (7-m chart datum), leeward (western), outer reefs at a total of 13 fishing grounds during three cruises (April-May 1999 (cruise 1), SeptemberNovember 1999 (cruise 2), February-March 2000 (cruise 3)) using a hierarchical sampling strategy (Dulvy et al. 2002). The barrier reef front of each fishing ground was divided into areas each $400 \mathrm{~m}$ in length on the appropriate marine chart. Fishing grounds of various sizes were sampled in a proportional manner by randomly selecting one third of all available areas (between three and eight areas). Three areas were surveyed at the smallest fishing grounds, whereas eight areas were sampled at the largest fishing ground. Replicates were selected in a haphazard manner. Sample areas within each fishing ground were relocated using geographical positioning system; however, we did not attempt to exactly relocate each replicate site among sampling dates. Consequently, variation 
at area level among sampling dates is a combination of both season and sample location. The data were aggregated across cruises and then nested as follows: replicate $<$ area $<$ fishing ground.

Fish densities were estimated using SCUBA underwater visual census of replicate $7-\mathrm{m}$ radius circular areas. The lengths and numbers of individuals $>8-\mathrm{cm}$ fork length were estimated for 182 diurnally active, reef-associated species from 18 families (Jennings and Polunin 1997; Samoilys and Carlos 2000; Dulvy et al. 2002). Estimates of fish length were converted to biomass using species-specific lengthweight conversions (Dulvy et al. 2002). If a length-weight relationship was not available, the relationship for a species of similar morphology in the same genus was used. The surveyor (NKD) was trained in underwater fish size estimation to a resolution of $1 \mathrm{~cm}$ using objects (polyvinyl chloride (PVC) pipe) of fixed sizes presented at a fixed distance (Bell et al. 1985; Darwall and Dulvy 1996). A total of 17 size estimation trials were conducted on eight different dates from February 1999 to April 2000. Trials were conducted at the same location at a depth of $7 \mathrm{~m}$, with an observer-object distance of $3 \mathrm{~m}$; the horizontal visibility was $10-15 \mathrm{~m}$. The precision in size estimation was calculated as 95\% confidence interval of the estimated object size. Observer error was estimated as the deviation of estimated size from the absolute object size.

The mean weight of all individuals of all species surveyed in each replicate was estimated as the total weight $(\mathrm{g})$ divided by the total number of individuals observed. All species observed in the underwater survey were included in the analysis. The weighted average maximum size $L_{\max }$ is an index consisting of the sum of each species' maximum observed size weighted by a measure of their biomass $\left(\mathrm{g} \cdot \mathrm{m}^{-2}\right)$ (Jennings et al. 1999a). It is calculated as the sum of individual species biomass multiplied by the species $L_{\max }$ as reported in the literature, all divided by the total biomass at each fishing ground. The maximum length of each species was collated from regional faunal references.

Size spectra were described by the slope and intercept of a linear regression of the community size frequency distribution. Fish abundance data were separated into 5-cm length classes $(11-65 \mathrm{~cm})$ and the densities of each length class were aggregated across sampling periods at the replicate level, providing nested averages at the level of fishing grounds. We tested for a negative relationship between the density of each size class and fishing intensity using linear regression. Size spectra were standardized to remove the correlation between slope and intercept by rescaling the midpoint of the length range to zero (Daan et al. 2003). This intercept value reflects the "height" of the size spectrum. Size spectra were constructed by regression of $\log _{10}(x+1)$ numbers on the rescaled $\log _{10}$ midpoint of each length class. Size spectra were calculated at the area level of replication and averaged across fishing grounds.

\section{Results}

The precision in object size estimation was generally high for an observer-object distance of $3 \mathrm{~m}$ in 10- to $15-\mathrm{m}$ horizontal visibility; the estimated object size was within $0.8 \mathrm{~cm}$ (mean 95\% CI) of the actual size across all size classes. Ob-
Fig. 1. Relationship between actual object size and estimated object size based on 17 underwater size estimation trials undertaken between February 1999 and April 2000 (mean \pm 95\% confidence interval). A dashed line with a slope of 1 is shown for comparison. Trials were conducted at the same location at a depth of $7 \mathrm{~m}$ in good visibility with an observer-object distance of $3 \mathrm{~m}$.

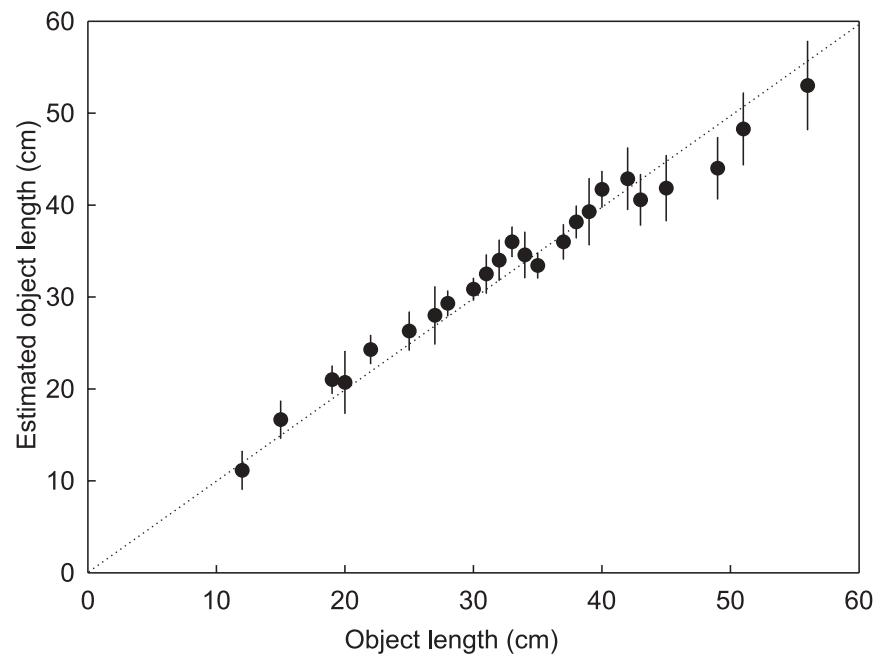

ject size was overestimated by an average of $1 \mathrm{~cm}$, particularly in the intermediate object sizes, and there was a tendency toward underestimation of smallest and largest object sizes (Fig. 1).

The abundance patterns and size metrics of the reef fish communities were relatively constant over six islands sampled over the year-long study period. The biomass and numbers of piscivores, invertivores, and herbivores varied significantly with fishing intensity over six fishing grounds, but generally their densities did not vary significantly with sample date. The number of invertivores varied significantly with sample date but not with fishing intensity (Table 1). The biomass densities of piscivores, invertivores, and herbivores declined significantly $(p<0.05)$ by $81 \%, 53 \%$, and $39 \%$, respectively, along the 13-ground fishing intensity gradient (Figs. 2a-2c). However, the numerical density of each trophic category was not significantly related to fishing intensity and was relatively constant along the 13-island fishing gradient (Figs. $2 d-2 f$ ).

The slopes of fish community length spectra varied significantly with fishing intensity $\left(F_{[5,90]}=11.9, p<0.001\right)$ and sampling date $\left(F_{[2,90]}=11.8, p<0.001\right)$ over six fishing grounds (Fig. $3 a$ ). The heights varied significantly with fishing intensity $\left(F_{[5,90]}=10.4, p<0.001\right)$, but not with sampling date $\left(F_{[2,90]}=0.4, p>0.05\right)$ over the six fishing grounds (Fig. $3 b)$. The slopes were steeper at higher fishing intensities across all 13 islands (Fig. $3 c ; F_{[1,11]}=5.0, p=$ 0.047). The heights of the length spectra also declined at higher fishing intensities across all 13 islands, but the change was not significant (Fig. $3 d ; F_{[1,11]}=1.5, p=0.25$ ).

The mean weight of individuals varied both with fishing intensity $\left(F_{[5,90]}=16.5, p<0.001\right)$ and sampling date $\left(F_{[2,90]}=34.9, p<0.001\right)$ over six grounds (Fig. 4). Both fishing intensity and sampling date explain similar levels of the variance in the mean weight of individual fish $(33 \%$ and $28 \%$, respectively). Overall, there was a $52 \%$ decline in 
Table 1. Two-way analysis of variance with sample date and fishing intensity as fixed factors and mean biomass $\left(\mathrm{g} \cdot \mathrm{m}^{-2}\right.$ ) or mean abundance (number of individuals $\cdot \mathrm{m}^{-2}$ ) of three trophic categories of coral reef fishes as dependent variables.

\begin{tabular}{|c|c|c|c|c|c|}
\hline Source & df & SS & $F$ & $p$ & $\begin{array}{l}\% \text { variance } \\
\text { explained }\end{array}$ \\
\hline \multicolumn{6}{|l|}{ Biomass $\left(\mathrm{g} \cdot \mathrm{m}^{-2}\right)$} \\
\hline \multicolumn{6}{|l|}{ Piscivore } \\
\hline Sample date & 2 & 0.196 & 2.453 & 0.093 & 3.3 \\
\hline Fishing intensity & 5 & 2.037 & 10.180 & $<0.001$ & 34.1 \\
\hline Interaction & 10 & 0.818 & 2.044 & 0.041 & 13.7 \\
\hline Residual & 73 & 2.922 & & & \\
\hline Total & 90 & 5.973 & & & \\
\hline \multicolumn{6}{|l|}{ Invertivore } \\
\hline Sample date & 2 & 1.317 & 6.138 & 0.003 & 10.8 \\
\hline Fishing intensity & 5 & 1.863 & 3.474 & 0.007 & 15.2 \\
\hline Interaction & 10 & 1.210 & 1.128 & 0.354 & 9.9 \\
\hline Residual & 73 & 7.830 & & & \\
\hline Total & 90 & 12.219 & & & \\
\hline \multicolumn{6}{|l|}{ Herbivore } \\
\hline Sample date & 2 & 0.011 & 0.255 & 0.776 & 0.5 \\
\hline Fishing intensity & 5 & 0.534 & 5.090 & $<0.001$ & 23.8 \\
\hline Interaction & 10 & 0.163 & 0.776 & 0.651 & 7.3 \\
\hline Residual & 73 & 1.533 & & & \\
\hline Total & 90 & 2.241 & & & \\
\hline \multicolumn{6}{|l|}{ Abundance $\left(\right.$ no. $\left.\cdot \mathbf{m}^{-2}\right)$} \\
\hline \multicolumn{6}{|l|}{ Piscivore } \\
\hline Sample date & 2 & 0.043 & 1.312 & 0.276 & 1.9 \\
\hline Fishing intensity & 5 & 0.757 & 9.146 & $<0.001$ & 33.4 \\
\hline Interaction & 10 & 0.220 & 1.330 & 0.231 & 9.7 \\
\hline Residual & 73 & 1.208 & & & \\
\hline Total & 90 & 2.265 & & & \\
\hline \multicolumn{6}{|l|}{ Invertivore } \\
\hline Sample date & 2 & 0.514 & 11.296 & $<0.001$ & 20.1 \\
\hline Fishing intensity & 5 & 0.153 & 1.347 & 0.254 & 6.0 \\
\hline Interaction & 10 & 0.153 & 0.673 & 0.746 & 6.0 \\
\hline Residual & 73 & 1.662 & & & \\
\hline Total & 90 & 2.562 & & & \\
\hline \multicolumn{6}{|l|}{ Herbivore } \\
\hline Sample date & 2 & 0.085 & 4.312 & 0.017 & 5.4 \\
\hline Fishing intensity & 5 & 0.564 & 11.446 & $<0.001$ & 35.8 \\
\hline Interaction & 10 & 0.173 & 1.753 & 0.085 & 11.0 \\
\hline Residual & 73 & 0.720 & & & \\
\hline Total & 90 & 1.574 & & & \\
\hline
\end{tabular}

mean weight of individuals from 225 to $117 \mathrm{~g}$, as estimated by linear regression, along the fishing intensity gradient, but this was not significant (Fig. $4 ; F_{[1,11]}=3.5, p=0.09$ ).

The average $L_{\max }$ of the community varied significantly with fishing intensity $\left(F_{[5,90]}=5.2, p<0.001\right)$ and sampling period $\left(F_{[2,90]}=8.4, p<0.001\right)$ over six fishing grounds (Fig. 5). But fishing intensity explained more of the variance in average $L_{\max }$ length than did sampling period: $20 \%$ compared with $13 \%$, respectively. Overall, the average $L_{\max }$ length declined significantly along the 13-island gradient in fishing intensity $\left(F_{[1,11]}=19.1, p 0.001\right)$. The average $L_{\max }$ of fish communities declined by $25 \%$, from 49 to $37 \mathrm{~cm}$ along the fishing intensity gradient.

The numerical abundance in the smaller size classes tended to increase slightly in response to exploitation (Fig. 6a). The numerical abundance of larger size classes $>26 \mathrm{~cm}$ declined along the fishing intensity gradient. These trends were significant $(p<0.05)$ only for the $26-$ to $30-\mathrm{cm}$ and $46-$ to $50-\mathrm{cm}$ size classes. The biomass of small length classes $<25 \mathrm{~cm}$ increased slightly in response to exploitation (Fig. 6b). The biomass of larger size classes $>26 \mathrm{~cm}$ declined with fishing intensity, but the biomass trends were not statistically significant (Fig. 6b).

The relative (percent) and absolute responses of each size class to exploitation were measured as the difference in predicted numbers or biomass between the lowest and highest fishing intensities as estimated using linear regression (Fig. 7). The three smallest size classes (spanning 11-25 cm) increased in both relative and absolute biomass and numbers per unit area (Fig. 7). This increase in numerical density was 
Fig. 2. Relationships between $(a-c)$ biomass and $(d-f)$ numbers of fishes in three trophic categories over 13 fishing grounds (mean \pm 95\% confidence interval): $(a, d)$ piscivores; $(b, e)$ invertivores; $(c, f)$ herbivores.

(a)

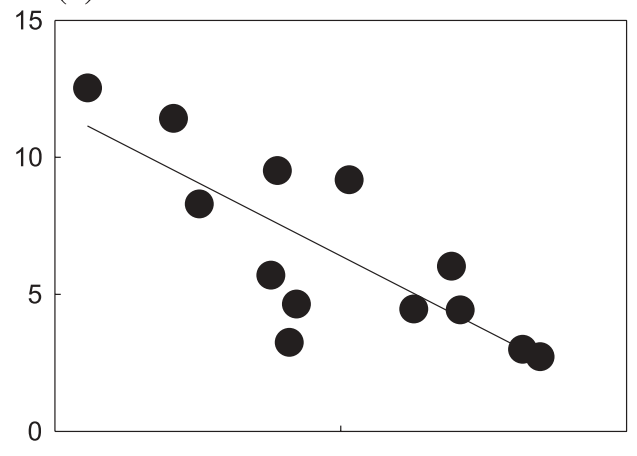

(b)

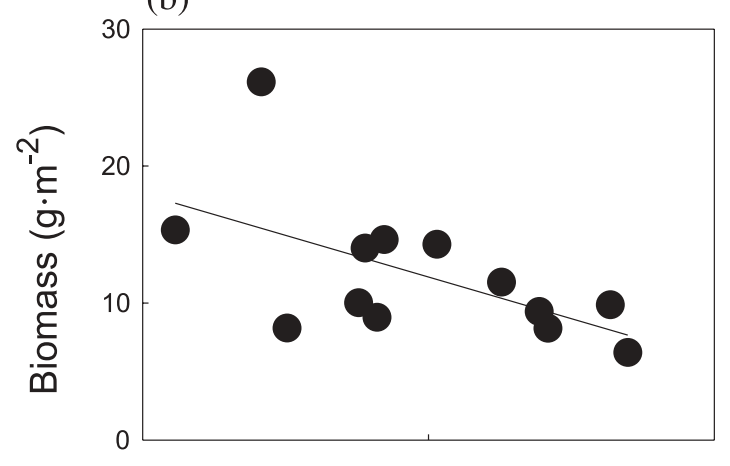

(c)

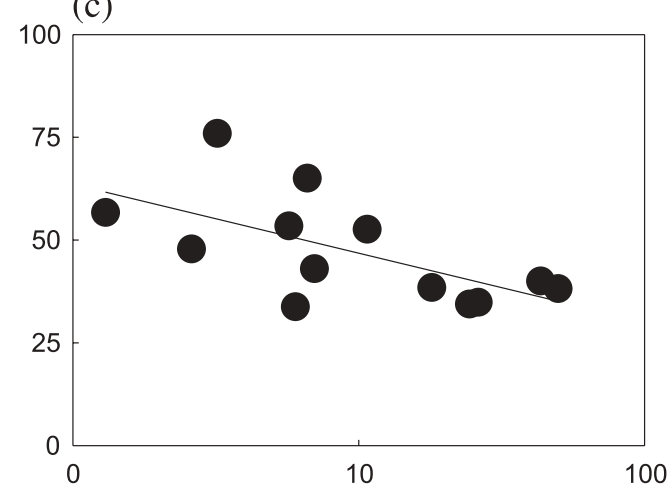

(d)

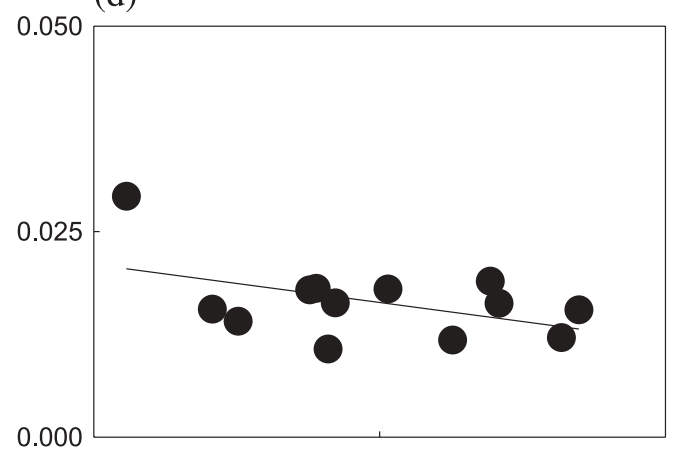

(e)

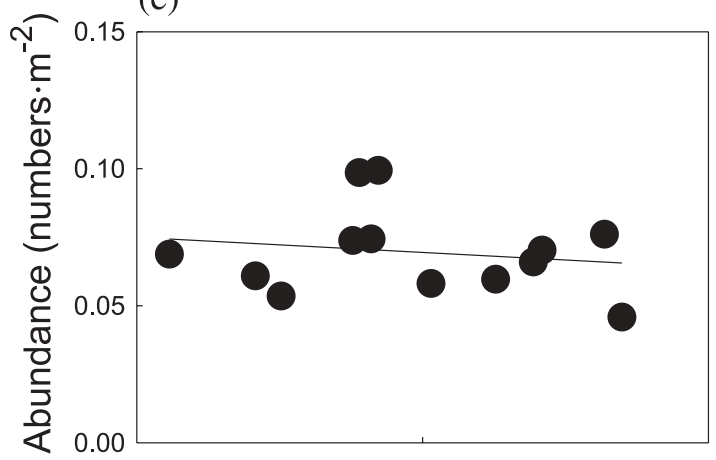

(f)

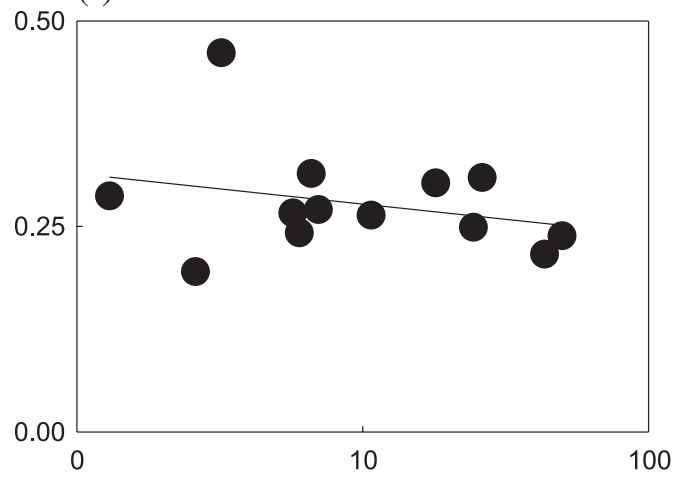

Fishing intensity (persons $\cdot(\mathrm{km} \text { reef front })^{-1}$ )

most apparent compared with the relative change in biomass (Figs. $7 a, 7 b$ ). The relative increase in biomass density was $2 \%$ for the 11 - to $15-\mathrm{cm}$ size class, $7 \%$ for the $16-$ to $20-\mathrm{cm}$ size class, and $17 \%$ for the $21-$ to $25-\mathrm{cm}$ size class (Fig. $7 a$ ). The relative increase in numerical density was $42 \%$ for the 11 - to $15-\mathrm{cm}$ size class, $16 \%$ for the $16-$ to $20-\mathrm{cm}$ size class, and $35 \%$ for the $21-$ to $25-\mathrm{cm}$ size class (Fig. $7 b$ ). The larger size classes $\geq 26 \mathrm{~cm}$ declined in relative biomass by $62 \%$ and numbers by $61 \%$ in response to exploitation (Figs. 7a, 7b).

The absolute increase in the combined biomass of the three smallest size classes was minor $\left(1.7 \mathrm{~g} \cdot \mathrm{m}^{-2}\right)$ compared with combined decline in the biomass of the larger size classes
(38.6 $\mathrm{g} \cdot \mathrm{m}^{-2}$ ) along this fishing intensity gradient (Fig. 7c). The absolute combined increase in the numerical density of the small size classes was substantial $\left(0.06\right.$ individuals $\left.\cdot \mathrm{m}^{-2}\right)$ compared with combined decline in the number of the larger size classes $\left(0.03 \mathrm{~g} \cdot \mathrm{m}^{-2}\right)$ along this fishing intensity gradient (Fig. 7d).

\section{Discussion}

We have presented evidence of substantial impacts of subsistence exploitation on the size metrics of island-scale coral reef fish communities in a Fijian archipelago. Specifically, 
Fig. 3. Relationships between size spectra metrics and fishing intensity. (a) Slope and $(b)$ height shown in six fishing grounds in each of three sample dates (mean $\pm 95 \%$ confidence interval). Cruise 1, solid bars; cruise 2, open bars; and cruise 3, hatched bars. (c) Slope and $(d)$ height averaged over a year and across all 13 fishing grounds.

(a)

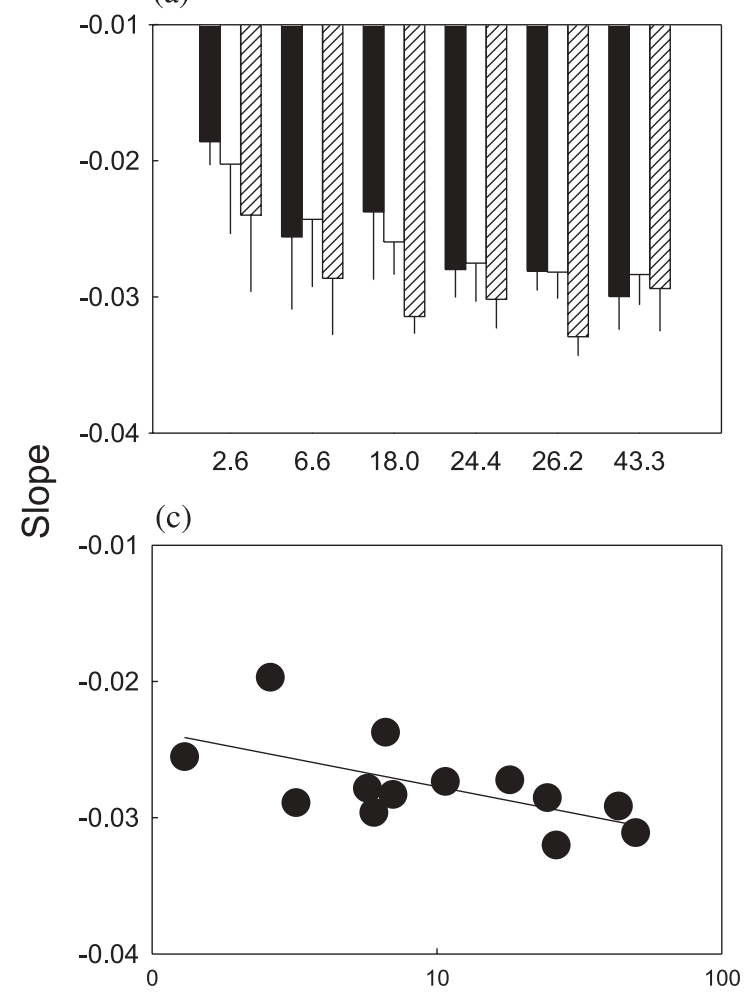

(b)

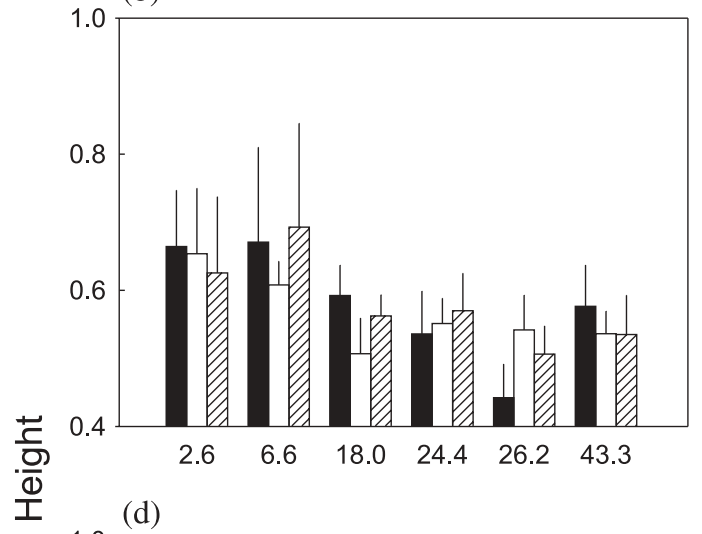

(d)

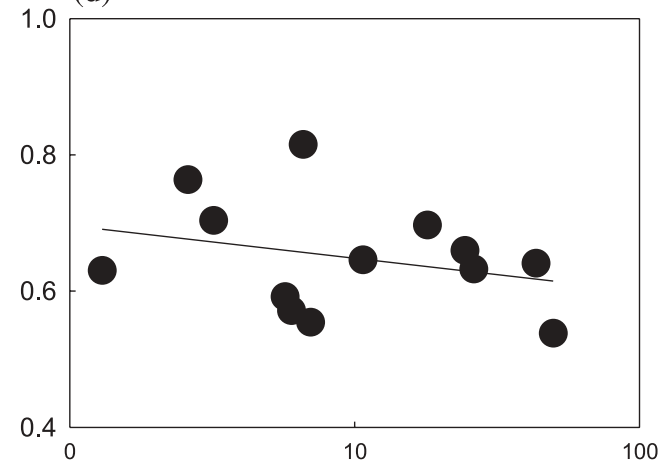

Fishing intensity (persons $\cdot(\mathrm{km} \text { reef front })^{-1}$ )

we have described declines in the slope of length spectra, average weight of individuals, and community $L_{\max }$ with increasing fishing pressure. The decline in each of these metrics can be interpreted in two ways: as increases in the abundance of smaller-bodied individuals or species and (or) as depletion of larger individuals or species. To differentiate between these possible interpretations, we should consider the effect of fishing on the abundance of each separate size class (Daan et al. 2003). We observed increases in the relative and absolute biomass and numbers of individuals in the three smallest sizes classes $(11-25 \mathrm{~cm})$, suggestive of some form of compensatory indirect effect of exploitation.

Previous studies using size metrics to describe the change in community structure generally examine change in the metric over time (Rice and Gislason 1996; Duplisea et al. 1997; Bianchi et al. 2000). It is usually assumed that time is a reasonable measure of fishing intensity, and it is acknowledged that other causal mechanisms may be linked to time. The Fijian study system offers an additional perspective, allowing the analysis of fishing effects across spatially replicated units at appropriately large scales. Previous work has shown that the simple metric of fishing intensity used here is related to the behaviour and activity of fishers, catch patterns, and fishery yields (Jennings and Polunin 1995a, 1995b, $1995 c$ ) Our findings, based on this verified measure of fishing intensity, support the findings of temporal analyses that size metrics are a useful ecosystem metric of exploitation effects.

Our conclusions should be considered in light of a number of factors and assumptions. Our study implicitly assumes that exploitation is the major structuring force; however, variable recruitment is also considered to be a major determinant of the abundance of broadcast-spawning fishes (e.g., Doherty 2002; Myers 2002). Many coral reef fishes spawn at multiple times throughout the course of a year, and during this time multiple postsettlement size classes would have grown to enter the censused size classes during the year-long duration of this study. If recruitment were an important factor in this study, at a point in time we would expect that sample date would explain a significant proportion of the variance in biomass and in the size metrics. Sample date explained comparatively little of the variance in fish community size metrics, suggesting this may not be the case. However, we caution that it is unlikely that the approach used here would be able to detect anything other than strongly synchronous recruitment events among species within trophic guilds across the study sites. The structural complexity of benthic habitats is known to influence reef fish community structure (e.g., Beukers and Jones 1998). Structural complexity was not explicitly examined here, but previous work has shown no significant variation in small-scale structural complexity of coral reef habitat across this fishing intensity 
Fig. 4. Relationships between the mean weight of individuals and fishing intensity $(a)$ in six fishing grounds in each of three sample dates (mean $\pm 95 \%$ confidence interval). Cruise 1 , solid bars; cruise 2, open bars; and cruise 3, hatched bars. (b) Mean weight of individuals averaged over a year and across all 13 fishing grounds.

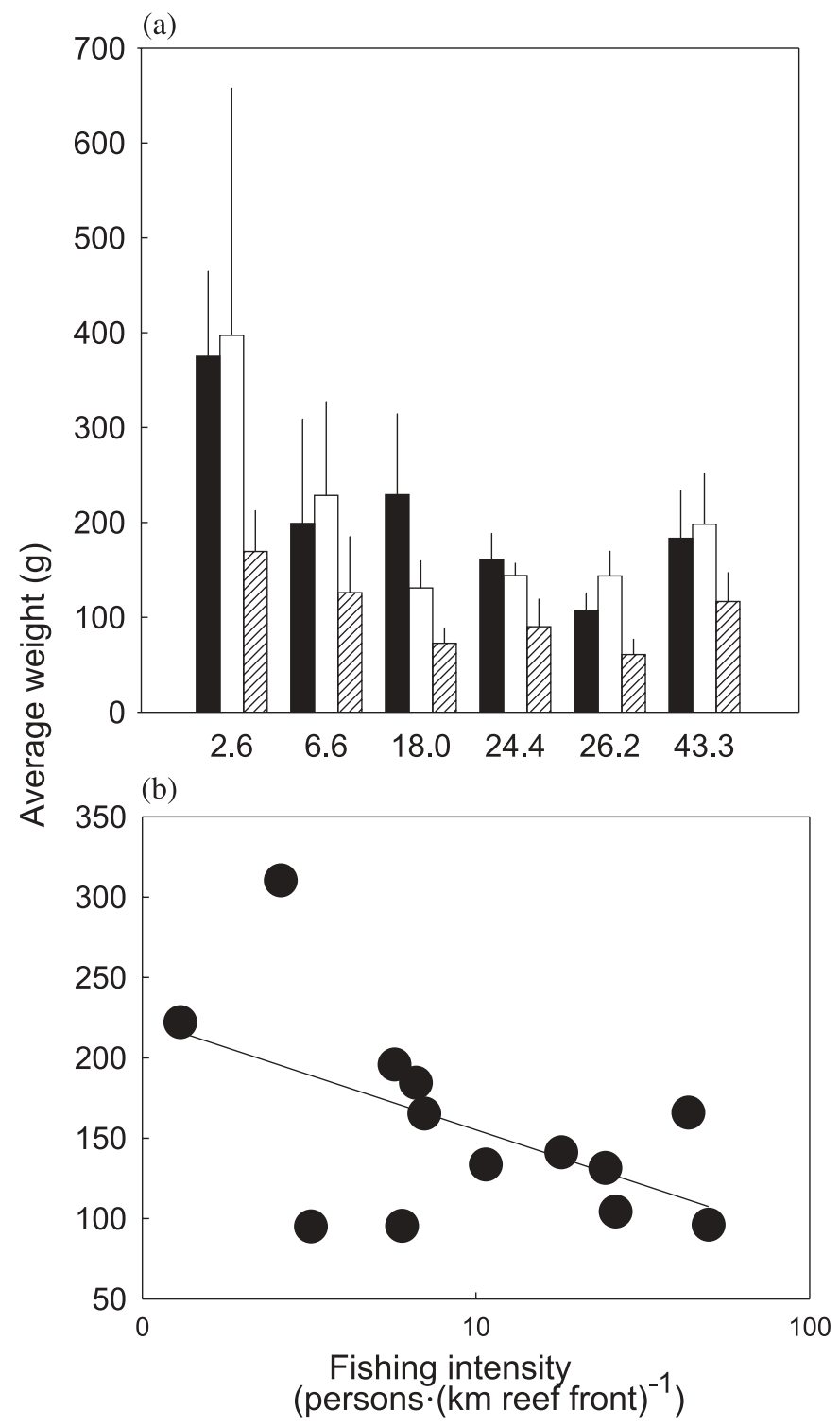

gradient (Dulvy et al. 2002). Finally, size estimation is unlikely to be a major source of bias in this study. The estimated level of precision and error is likely to represent an upper limit because size estimation trials were conducted in horizontal visibilities between 10 and $15 \mathrm{~m}$, whereas actual fieldwork was carried out in locations where horizontal visibility was more favorable less than $20 \mathrm{~m}$. The precision and error in size estimation was less than the width of the size category $(5 \mathrm{~cm})$ chosen for analysis.

Piscivorous fishes are significant consumers of fish biomass, and predation is an important source of mortality and widely thought to be an important structuring force at subpopulation scales on coral reefs (Hixon and Webster 2002). However, other larger scale, species-based studies of predator-
Fig. 5. Relationships between the weighted average maximum size $\left(L_{\max }\right)$ of the community and fishing intensity $(a)$ in six fishing grounds in each of three sample dates (mean $\pm 95 \%$ confidence interval). Cruise 1, solid bars; cruise 2, open bars; and cruise 3 , hatched bars. (b) Community $L_{\max }$ averaged over a year and across all 13 fishing grounds.
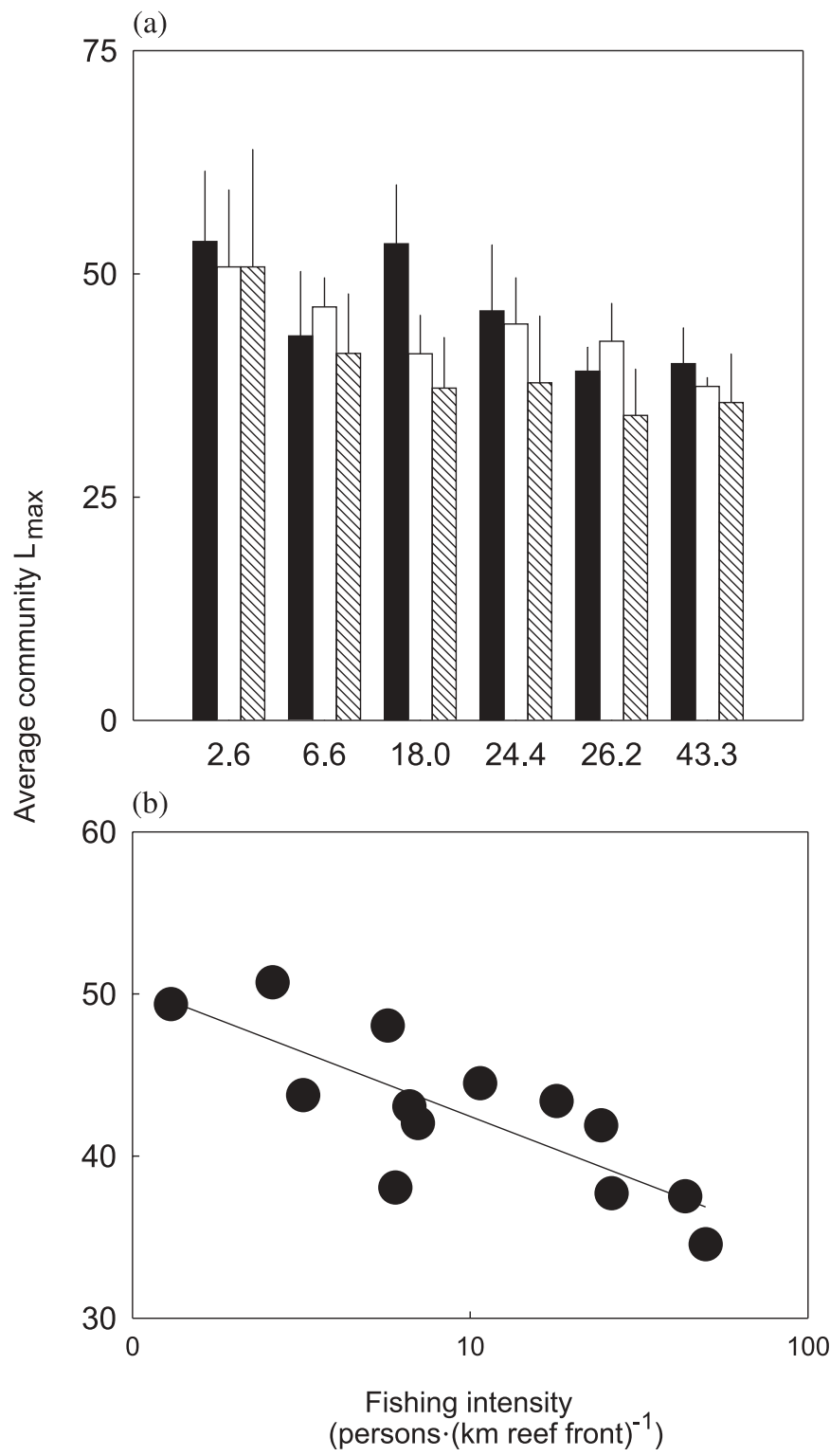

prey coupling on coral reefs have been less conclusive (Jennings and Polunin 1997; Russ and Alcala 1998). A size spectrum approach implies a predation-based structuring mechanism, in the sense that fish are morphometrically constrained to eat smaller-bodied prey (Pope et al. 1994; Scharf et al. 2000; Karpouzi and Stergiou 2003). Consequently, the removal of larger size classes must result in reduced predation on smaller size classes. This may be the case only if trophic level is positively related to body size. While trophic level generally appears to scale with gape size and body size in fishes (e.g., Karpouzi and Stergiou 2003), there is some evidence that the body size - trophic level relationship is weak or negative in some fish species (Jennings et al. 2002). 
Fig. 6. Relationships between fish density in $(a)$ numbers and $(b)$ biomass of each 5 -cm length class and fishing intensity over 13 fishing grounds. A solid line indicates significant regression relationship at $p<0.05$. Note that the $y$ axis scale differs among plots.
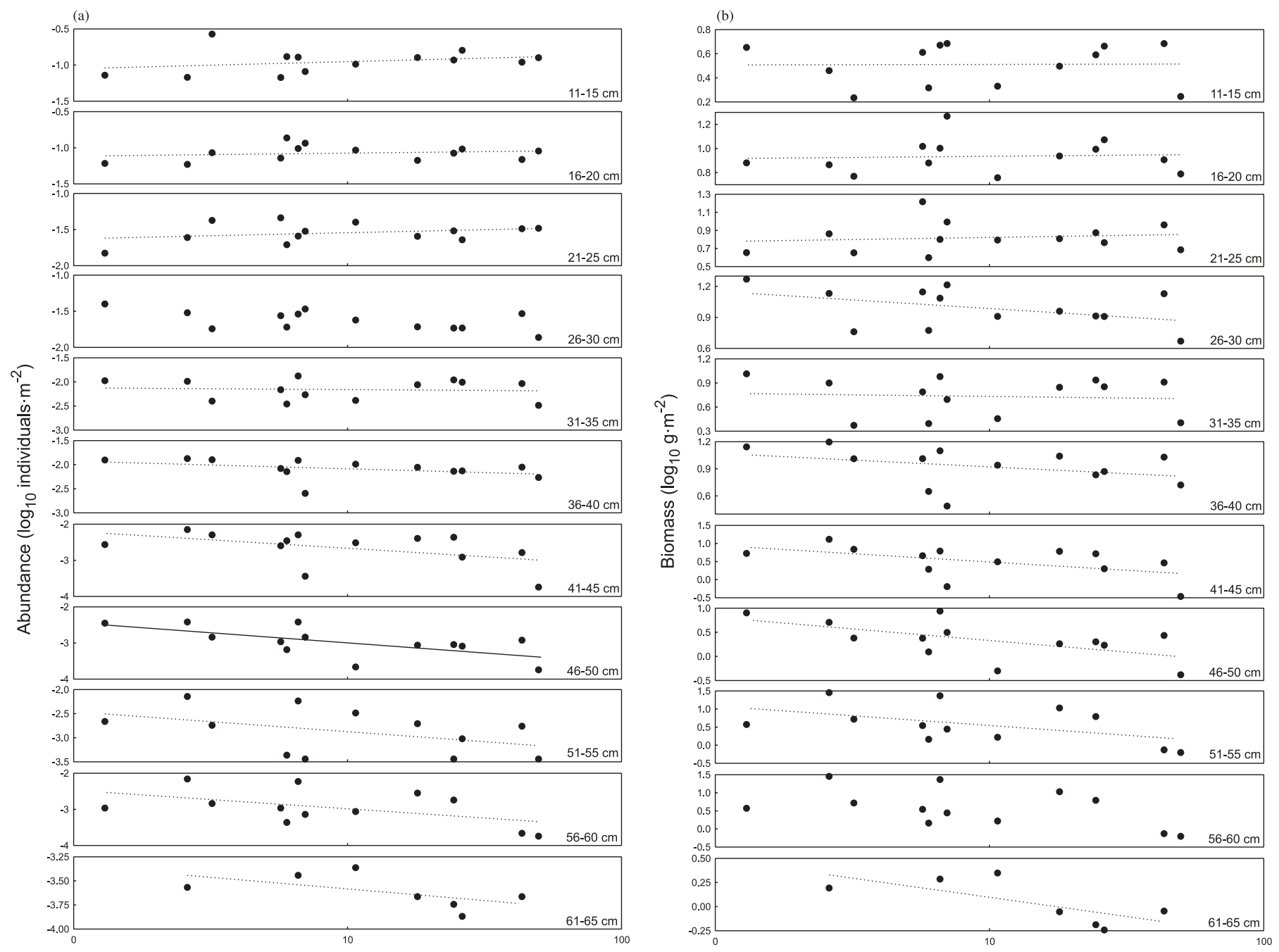

Fishing intensity (persons $\left.\cdot(\mathrm{km} \text { reef front })^{-1}\right)$

Competitive release may contribute to explaining the observed increase in the abundance of smaller size classes. The preferential removal of large territorial herbivores such as parrotfishes (Scaridae) and surgeonfishes (Acanthuridae) could conceivably open space allowing the proliferation of smaller bodied herbivores, such as the territorial farmer damselfishes (Pomacentridae). Both body size - trophic level coupling and competitive interactions of coral reef fishes deserve further exploration. Our data suggest ecological processes, such as predation, may have a role in structuring coral reef fish communities at large spatial scales.

Our findings suggest some form of compensatory increase in numbers of small fishes as an indirect effect of exploitation on coral reefs. Similar evidence for compensatory increases as a consequence of the removal of larger fishes at larger spatial scales has recently been detected in North Sea and Celtic Sea fish communities using size-based approaches (Blanchard et al. 2003; Daan et al. 2003). This suggests the strength of predator-prey coupling in fish communities may be stronger than previously thought. It has been suggested that fishing strategies that result in increases in the production of prey species might be preferred (Jones 1982). The release is most apparent as an increase in the absolute numbers of small fishes $(25 \mathrm{~cm}$ in length) along the fishing gradient; however, the corresponding increase in the absolute and relative biomass of the smallest size classes is comparatively minor and insufficient to offset the declines in the numbers and biomass of the larger size classes. Our findings indicate that increases in production of small size class are not expected to compensate for the long-term losses of removing larger size classes.

\section{Acknowledgements}

We thank Robin South and the staff of the Marine Studies Programme at the University of the South Pacific for providing facilities and continued support; the Tui Nayau, chiefs, and turaganikoro of all the islands for granting permission for this study; K. Wynn, R.E. Mitchell, C. Glendinning, A. Haddock, R. Ekeheien, C. Gough, and B. Vasconcellos for logistical support and field assistance. The standardization of size spectra and the analysis of the numerical response of different size classes was based on unpublished ideas developed by N. Daan, H. Gislason, J. Pope, and J. Rice, and we 
Fig. 7. The relative $(a, b)$ and absolute $(c, d)$ responses to exploitation of the biomass and numbers in each length class versus the length class upper point.
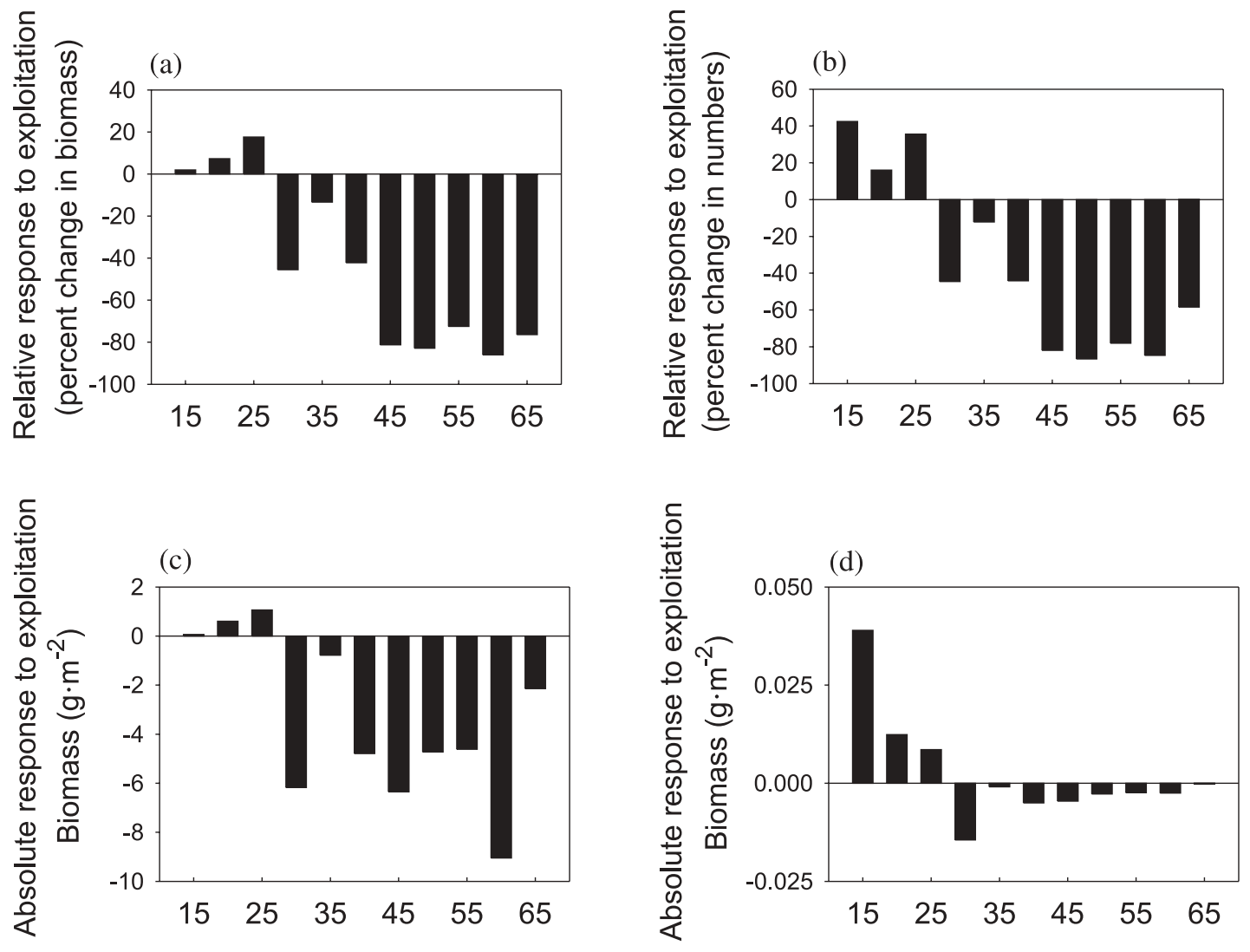

\section{Length class upper point $(\mathrm{cm})$}

thank N. Daan for bringing this approach to our attention. We thank S. Jennings, J. Blanchard, and two anonymous referees for their valuable comments. This study was funded by the Natural Environment Research Council, U.K., and Defra (MFD 0729).

\section{References}

Ault, J.S., Bohnsack, J.A., and Meester, G. 1998. A retrospective (1979-1995) multispecies assessment of coral reef fish stocks in the Florida Keys. Fish. Bull. 96: 395-414.

Bell, J.D., Craik, G.J.S., Pollard, D.A., and Russell, B.C. 1985. Estimating length frequency distributions of large reef fish underwater. Coral Reefs, 4: 41-44.

Beukers, J.S., and Jones, G.P. 1998. Habitat complexity modifies the impact of piscivores on a coral reef fish population. Oecologia, 114: $50-59$.

Bianchi, G., Gislason, H., Graham, K., Hill, L., Jin, X., Koranteng, K., Manickchand-Heileman, S., Payá, I., Sainsbury, K., Sanchez, F., and Zwanenburg, K. 2000. Impact of fishing on size composition and diversity of demersal fish communities. ICES J. Mar. Sci. 57: 558-571.

Blanchard, J.L., Dulvy, N.K., Ellis, J.E., Pinnegar, J.K., and Jennings, S. 2003. Ecological and environmental factors influence size-based metrics of Celtic Sea fish communities. ICES CM 2003/N:04: 1-28.
Carscadden, J.E., Frank, K.T., and Leggett, W.C. 2001. Ecosystem changes and the effects on capelin (Mallotus villosus), a major forage species. Can. J. Fish. Aquat. Sci. 58: 73-85.

Charnov, E.L. 1993. Life history invariants. Oxford University Press, Oxford.

Daan, N., Gislason, H., Pope, J.G., and Rice, J. 2003. Changes in the North Sea fish community: evidence of indirect effects of fishing? ICES CM 2003/N:10: 1-11.

Darwall, W.R.T., and Dulvy, N.K. 1996. An evaluation of the suitability of non-specialist volunteer researchers for coral reef fish surveys. Mafia Island, Tanzania - a case study. Biol. Conserv. 78: $223-231$.

Denney, N.H., Jennings, S., and Reynolds, J.D. 2002. Life history correlates of maximum population growth rates in marine fishes. Proc. R. Soc. Lond. B Biol. Sci. 269: 2229-2237.

Doherty, P.J. 2002. Variable replenishment and the dynamics of reef fish populations. In Coral reef fishes: dynamics and diversity in a complex system. Edited by P.F. Sale. Academic Press Ltd., London. pp. 327-355.

Dulvy, N.K., Metcalfe, J.D., Glanville, J., Pawson, M.G., and Reynolds, J.D. 2000. Fishery stability, local extinctions and shifts in community structure in skates. Conserv. Biol. 14: 283-293.

Dulvy, N.K., Mitchell, R.E., Watson, D., Sweeting, C., and Polunin, N.V.C. 2002. Scale-dependant control of motile epifaunal community structure along a coral reef fishing gradient. J. Exp. Mar. Biol. Ecol. 278: 1-29.

Duplisea, D.E., Kerr, S.R., and Dickie, L.M. 1997. Demersal fish biomass size spectra on the Scotian Shelf, Canada: species re- 
placement at the shelfwide scale. Can. J. Fish. Aquat. Sci. 54: $1725-1735$.

Gislason, H., and Rice, J. 1998. Modelling the response of size and diversity spectra of fish assemblages to changes in exploitation. ICES J. Mar. Sci. 55: 362-370.

Graham, N.A.J., Evans, A.J., and Russ, G.R. 2003. The effects of marine reserve protection on the trophic relationships of reef fishes on the Great Barrier Reef. Environ. Conserv. 30: 200-208.

Hixon, M.A., and Webster, M.S. 2002. Density dependence in reef fish populations. In Coral reef fishes:dynamics and diversity in a complex system. Edited by P.F. Sale. Academic Press Ltd., London. pp. 303-325.

Hutchings, J.A. 2002. Life histories. In Handbook of fish and fisheries. Edited by P.J.B. Hart and J.D. Reynolds. Blackwell Science Ltd., Oxford. pp. 149-174.

Jennings, S., and Polunin, N.V.C. 1995a. Comparative size and composition of yield from six Fijian reef fisheries. J. Fish Biol. 46: $28-46$.

Jennings, S., and Polunin, N.V.C. 1995b. Effects of fishing on the biomass and structure of target reef fish communities. J. Anim. Ecol. 33: 400-412.

Jennings, S., and Polunin, N.V.C. 1995c. Relationships between catch and effort in Fijian multispecies reef fisheries subject to different levels of exploitation. Fish. Manag. Ecol. 2: 89-101.

Jennings, S., and Polunin, N.V.C. 1996. Effects of fishing effort and catch rate upon the structure and biomass of Fijian reef fish communities. J. Appl. Ecol. 33: 400-412.

Jennings, S., and Polunin, N.V.C. 1997. Impacts of predator depletion by fishing on the biomass and diversity of non-target reef fish communities. Coral Reefs, 16: 71-82.

Jennings, S., Reynolds, J.D., and Mills, S.C. 1998. Life history correlates of responses to fisheries exploitation. Proc. R. Soc. Lond. B Biol. Sci. 265: 333-339.

Jennings, S., Greenstreet, S.P.R., and Reynolds, J.D. 1999a. Structural change in an exploited fish community: a consequence of differential fishing effects on species with contrasting life histories. J. Anim. Ecol. 68: 617-627.

Jennings, S., Reynolds, J.D., and Polunin, N.V.C. 1999b. Predicting the vulnerability of tropical reef fishes to exploitation using phylogenies and life histories. Conserv. Biol. 13: 1466-1475.

Jennings, S., Greenstreet, S.P.R., Hill, L., Piet, G.J., Pinnegar, J.K., and Warr, K.J. 2002. Long-term trends in the trophic structure of the North Sea fish community: evidence from stable-isotope analysis, size-spectra and community metrics. Mar. Biol. 141: 1085-1097.

Jones, R. 1982. Ecosystems, food chains and fish yields. In Theory and management of tropical fisheries. Edited by D. Pauly and G.I. Murphy. International Center for Living Aquatic Resources, Manila (ICLARM).

Kaiser, M.J., and Jennings, S. 2001. An ecosystem perspective on conserving targeted and non-targeted species. In Conservation of exploited species. Edited by J.D. Reynolds, G.M. Mace, K.H. Redford, and J.G. Robinson. Cambridge University Press, Cambridge. pp. 343-369.
Karpouzi, V.S., and Stergiou, K.I. 2003. The relationships between mouth size and shape and body length for 18 species of marine fishes and their trophic implications. J. Fish Biol. 62: 1353-1365.

Kerr, S.R., and Dickie, L.M. 2001. The biomass spectrum: a predator-prey theory of aquatic production. Columbia University Press, New York.

Myers, R.A. 2002. Recruitment: understanding density-dependence in fish populations. In Handbook of fish and fisheries. Edited by P.J.B. Hart. Blackwell Science Ltd., Oxford. pp. 123-148.

Myers, R.A., Brown, K.G., and Barrowman, N.J. 1999. The maximum reproductive rate of fish at low population sizes. Can. J. Fish. Aquat. Sci. 56: 2404-2419.

Pauly, D., Christensen, V., Dalsgaard, J., Froese, R., and Torres, F., Jr. 1998. Fishing down marine food webs. Science (Washington, D.C.), 279: 860-863.

Pennings, S.C. 1996. Indirect interactions on coral reefs. In Life and death of coral reefs. Edited by C. Birkland. Chapman \& Hall Inc., New York. pp. 249-272.

Pinnegar, J.K., Polunin, N.V.C., Francour, P., Badalamenti, F., Chemello, R., Harmelin-Vivien, M.-L., Hereu, B., Milazzo, M., Zabala, M., D'Anna, G., and Pipitone, C. 2000. Trophic cascades in benthic marine ecosystems: lessons for fisheries and protected-area management. Environ. Conserv. 27: 179-200.

Pinnegar, J.K., Jennings, S., O'Brien, C.M., and Polunin, N.V.C. 2002. Long-term changes in trophic level of the Celtic Sea fish community and fish market price distribution. J. Appl. Ecol. 39: 377-390.

Pope, J.G., Shepherd, J.G., and Webb, J. 1994. Successful surfriding on size spectra: the secret of survival in the sea. Philos. Trans. R. Soc. Lond. B Biol. Sci. 343: 41-49.

Reynolds, J.D., Jennings, S., and Dulvy, N.K. 2001. Life histories of fishes and population responses to exploitation. In Conservation of exploited species. Edited by J.D. Reynolds, G.M. Mace, K.H. Redford, and J.G. Robinson. Cambridge University Press, Cambridge. pp. 147-168.

Rice, J., and Gislason, H. 1996. Patterns of change in the size spectra of numbers and diversity of the North Sea fish assemblage, as reflected in surveys and models. ICES J. Mar. Sci. 53: 1214-1225.

Robertson, D.R. 1998. Implications of body size for interspecific interactions and assemblage organization among coral-reef fishes. Aust. J. Ecol. 23: 252-257.

Russ, G.R., and Alcala, A.C. 1998. Natural fishing experiments in marine reserves 1983-1993: roles of life history and fishing intensity in family responses. Coral Reefs, 17: 399-416.

Samoilys, M.A., and Carlos, G. 2000. Determining methods of underwater visual census for estimating the abundance of coral reef fishes. Environ. Biol. Fishes, 57: 289-304.

Scharf, F.S., Juanes, F., and Rountree, R.A. 2000. Predator-prey size relationships of marine fish predators: interspecific variation and the effects of ontogeny and body size on niche breadth. Mar. Ecol. Prog. Ser. 208: 229-248.

Worm, B., and Myers, R.A. 2003. Top-down versus bottom-up control in oceanic food webs: a meta-analysis of cod-shrimp interactions in the North Atlantic. Ecology, 84: 162-173. 